\title{
Comparative efficacy of vasoactive medications in patients with septic shock: a network meta-analysis of randomized controlled trials
}

\author{
Lu Cheng ${ }^{1}$, Jing Yan², Shutang Han ${ }^{3}$, Qiuhua Chen ${ }^{1}$, Mingqi Chen ${ }^{1}$, Hua Jiang ${ }^{1}$ and Jun Lu $^{{ }^{*}}$
}

\begin{abstract}
Background: Catecholamines, especially norepinephrine, are the most frequently used vasopressors for treating patients with septic shock. During the recent decades, terlipressin, vasopressin V1A agonist, and even $\mathrm{Ca}^{2+}$ sensitizer were increasingly used by physicians. The aim of this study is to compare the efficacy of such different kinds of vasoactive medications on mortality among patients with septic shock.

Methods: Relevant randomized controlled trials were identified by searching PubMed, Embase, Web of Science, and the Cochrane Central Register of Controlled Trials updated to February 22, 2018. A network meta-analysis was performed to evaluate the effect of different types of vasoactive medications. The primary outcome was 28-day mortality. Intensive care unit (ICU) mortality, hospital and ICU length of stay (LOS), and adverse events were also assessed.
\end{abstract}

Results: A total of 43 trials with 5767 patients assessing 17 treatment modalities were included. Treatments ranking based on surface under the cumulative ranking curve values from largest to smallest were NE/DB 85.9\%, TP 75.1\%, NE/EP 74.6\%, PI 74.1\%, EP 72.5\%, VP 66.1\%, NE 59.8\%, PE 53.0\%, DA 42.1\%, DX 38.2\%, SP 27.0\%, PA 24.3\%, EX 22.8\%, LE 21.5\%, and DB 13.3\% for 28-day mortality. Treatments ranking for ICU mortality were TP/NE 86.4\%, TP 80.3\%, TP/ DB/NE 65.7\%, VP/NE 62.8\%, NE 57.4\%, VP 56.5\%, PE 48.4\%, DA 33.0\%, PA 27.5\%, LE 22.1\%, and DB 9.9\%. The incidence of myocardial infarction was reported with NE/EP 3.33\% ( $n=1$ of 30), followed by EP $3.11 \%$ ( $n=5$ of 161), and then VP 3.10\% ( $n=19$ of 613 ), NE 3.03\% ( $n=43$ of 1417), DA 2.21\% ( $n=19$ of 858), NE/DB 2.01\% ( $n=4$ of 199), LE $1.16 \%$ ( $n=3$ of 258), and PA 0.39\% ( $n=1$ of 257). The incidence of arrhythmia was reported with DA 26.01\% ( $n$ $=258$ of 992), followed by EP 22.98\% ( $n=37$ of 161), and then NE/DB 20.60\% ( $n=41$ of 199), NE/EP 20.0\% ( $n=6$ of 30), NE $8.33 \%$ ( $n=127$ of 1525), LE 5.81\% ( $n=15$ of 258), PA 2.33\% ( $n=6$ of 257$)$, and VP 1.67\% ( $n=10$ of 600$)$.

Conclusions: The use of norepinephrine plus dobutamine was associated with lower 28-day mortality for septic shock, especially among patients with lower cardiac output.

Keywords: Sepsis, Septic shock, Vasoactive agent, Hemodynamic, Norepinephrine, Terlipressin, Dopamine, Vasopressin

\footnotetext{
*Correspondence: aztec0403@163.com

${ }^{1}$ Department of Intensive Care Unit, Affiliated Hospital of Nanjing University

of Chinese Medicine, 155 Hanzhong Road, Nanjing 210029, China

Full list of author information is available at the end of the article
}

(c) The Author(s). 2019 Open Access This article is distributed under the terms of the Creative Commons Attribution 4.0 International License (http://creativecommons.org/licenses/by/4.0/), which permits unrestricted use, distribution, and reproduction in any medium, provided you give appropriate credit to the original author(s) and the source, provide a link to the Creative Commons license, and indicate if changes were made. The Creative Commons Public Domain Dedication waiver (http://creativecommons.org/publicdomain/zero/1.0/) applies to the data made available in this article, unless otherwise stated. 


\section{Background}

Sepsis is a life-threatening organ dysfunction caused by dysregulated host response to infection, while septic shock is a subset of sepsis with circulatory and cellular/ metabolic dysfunction associated with a higher risk of mortality [1,2]. Septic shock is a major healthcare problem that contributes to the most common causes of death in the intensive care unit (ICU) [3]. Septic shock is a distributive shock with decreased systemic vascular resistance and mean arterial pressure (MAP) [4]. If hemodynamic status is not maintained, mortality rates for septic shock may even reach 50\% [5]. Management of septic shock involves treating the underlying cause, fluid resuscitation, and infusion of vasoactive medications to achieve the goal of increased perfusion blood pressure. The vasoactive medications may increase vascular resistance and raise MAP and perfusion in tissues and organs [6].

Current guidelines recommend the use of norepinephrine as the first-line vasopressor with intent to target MAP [7]. Adrenergic agonists and vasopressin analogs are used most commonly by physicians. Some new drugs were used increasingly during the last decades. Selepressin was even considered to be able to replace norepinephrine while maintaining adequate MAP, improving fluid balance and shorten the mechanical ventilation time [8]. To date, there were no studies that synthetically compared the effects of all these vasoactive medications. Methodologically, existing studies only pooled the direct comparisons between the two vasoactive medications $[9,10]$.

A network meta-analysis (NMA) was used to combine direct within-trial between-drug comparisons with indirect evidence from the other trials [11]. In this study, NMA was performed to update current clinical study data and determine the association among treatments with catecholamine, vasopressin, inotropic drug, and other vasoactive medications on mortality, length of stay (LOS), and adverse events.

\section{Methods}

The study protocol was registered in the International Prospective Register of Systematic Reviews (CRD42018090437). The presentation of this study followed the Preferred Reporting Items for Systematic reviews and Meta-Analyses guidelines for reporting NMA [12].

\section{Patients}

Patients with septic shock who received vasoactive medications were enrolled in this network meta-analysis.

\section{Interventions and comparisons}

The interventions of interest were specified with vasoactive medications, irrespective of dose, duration, or co-intervention. The vasoactive medications were compared with an inactive control intervention (e.g., placebo or standard care), or with an active control intervention (e.g., other vasoactive medications or combination therapy with vasoactive medications).

\section{Outcomes}

The primary outcome was death from any cause and was assessed 28 days after the start of infusions (28-day mortality). The mortality at 28 to 30 days was considered equivalent to 28 -day mortality. Death between the start of infusions and when the patients were discharged from the ICU (ICU mortality) was also assessed. Secondary outcomes were ICU and hospital length of stay. Length of stay in the ICU and hospital was defined as the time spent in the ICU or hospital, respectively, during the index hospitalization. The adverse events were also evaluated and defined as any undesirable outcomes that included myocardial infarction, arrhythmia, or peripheral ischemia.

\section{Setting}

Randomized controlled trials (RCTs) were included, irrespective of the publication date, setting, and risk of bias. Studies with English and Chinese languages were both included.

\section{Search strategy}

Studies were identified by electronically searching MEDLINE, Embase, Web of Science and the Cochrane Central Register for Controlled Trials (CENTRAL), using search terms describing the study design, intervention, or comparator updated to February 22, 2018. The specific search strategy in MEDLINE is presented in Additional file 1 . Hand searching the references of eligible studies was performed and consulted to identify additional trials.

\section{Data collection and extraction}

The study data were collected and extracted using a standardized form. Two authors independently screened the titles and abstracts for eligibility. Full papers were assessed to confirm disagreement in existence according to the exclusion criteria by the two authors who recorded the main reason for the exclusion. Any disagreement was resolved by a third author through consensus.

The inclusion criteria included (1) patients who were definitely diagnosed with septic shock, (2) studies that compared the effect of vasoactive medications, and (3) randomized controlled trial studies.

The exclusion criteria were (1) non-relevant intervention, (2) studies that failed to acquire outcomes of interest, (3) non-adult studies, and (5) non-RCT such as 
review, letter, before and after study, observational study, case-control study, and case report.

\section{Assessment of risk of bias}

The Cochrane Collaboration Tool was used to assess the risk of bias for the included studies [13]. The risk of bias was evaluated using the following domains: (1) random sequence generation, (2) allocation concealment, (3) blinding of participants and personnel, (4) blinding of outcome assessment, (5) incomplete outcome data, (6) selective reporting, and (7) other bias. Judgment as "low," "unclear," or "high" risk of bias was provided in each of the domains for each study. Studies with low risk of bias for all the domains were considered to be at low risk of bias. Studies with high risk of bias for one or more domains were considered to be at high risk of bias. Two authors assessed the performance and detection bias separately. The disagreements were resolved by discussion.

\section{Statistical analysis}

Odds ratio (OR) with $95 \%$ confidence interval (CI) was used to calculate the difference for dichotomous outcomes, while standardized mean difference (SMD) with 95\% CI was used for continuous variables. If the studies only reported the median and measure of dispersion, the data were converted to mean and standard deviation assuming a normal distribution, by using two simple formulae [14].

Clinical and methodological heterogeneity were assessed according to the study characteristics. Statistical heterogeneity among direct comparisons of the included trials was assessed by using the fixed-effects model with Mantel-Haenszel weighting, because some comparisons were expected to show heterogeneity [15]. Sensitivity analysis was conducted by sequentially omitting one study each time, to identify the potential influence on whether there was a significant heterogeneity among the included studies.

Transitivity assumption is a key assumption in network meta-analysis. In our study, norepinephrine was used as a reference treatment in all analyses. For each intervention, the estimate versus norepinephrine was synthesized to get an overall summary estimate, and a hierarchy of interventions based on the overall estimate was obtained. The pooled effect size for each intervention was synthesized to obtain an overall weighted average using inverse variance as weights. The assumption of consistency implies that the direct and indirect evidence were in statistical agreement for every pairwise comparison in a network. The local inconsistency was evaluated by using the loop-specific approach, while the "design-by-treatment" model was used to describe and check the assumption of inconsistency in the entire network for each outcome [16, 17]. Contribution plot was performed to evaluate the effect that each trial contributed to the NMA. The contribution of a study to the direct estimate is the percentage of information that comes from a specific study in the estimation of a direct relative effect using standard pairwise meta-analysis. For studies in which patients crossed over to another treatment, the analysis was still according to the first assigned group. The potential publication bias was evaluated by using funnel plots.

The key NMA technique is associated with evaluating the assumption underlying the statistical synthesis of direct and indirect evidence [18]. The surface under the cumulative ranking curve (SUCRA) values and rankograms were used to present the hierarchy of interventions for each outcome. SUCRA values show the percentage of effectiveness each intervention achieves compared to a hypothetical best intervention, which is always the best without uncertainty [19]. Generally, SUCRA values are interpreted as probabilities, and the larger the probability, the better the treatment.

The modified Grades of Recommendation, Assessment, Development and Evaluation (GRADE) tool for NMAs was used to evaluate the quality of evidence [20]. The quality results were classified as follows: (1) high quality-further research is very unlikely to change the confidence in the estimated effect; (2) moderate quality-further research is likely to have an important impact on the confidence in the estimated effect and may change the estimate; (3) low quality-further research is very likely to have an important impact on the confidence in the estimated effect and is likely to change the estimate; and (4) very low quality-where any estimated effect is highly uncertain [21].

The results were considered statistically significant at two-sided $P$ value less than 0.05 . All statistical analyses were performed using STATA 14.0 software (StataCorp, College Station, TX, USA).

\section{Results}

A total of 601 studies from electronic databases were identified, and 166 duplicated studies were removed. After an initial evaluation of the titles and abstracts, 365 studies were excluded because they did not meet the predefined inclusion criteria. The remaining 70 studies were identified for full review, and 27 studies were excluded due to inappropriate study design, lack of outcomes of interest to review, and other reasons. Eventually, 43 randomized controlled trials with 5767 septic shock patients were included. The included studies were presented in Additional file 1. The flow diagram for the study inclusion according to PRISMA is shown in Fig. 1. These trials were conducted in 17 different countries, with Italy contributing the most (7 trials, 
16.3\%). The studies were published in English or Chinese. A total of 17 different interventions were identified in papers published between 1993 and 2017. The designs of the included RCTs were presented in Table 1.

The detailed management description and baseline characteristics of these trials were presented in Additional file 1. Norepinephrine was used most frequently in 23 trials. Vasopressin and levosimendan were both used in 9 trials. Dobutamine and dopamine were used in 7 and 6 trials, respectively, and epinephrine was used in 4 trials, while enoximone, pituitrin, and selepressin were all used in 1 trial. The combination of norepinephrine and dopamine was used in 4 trials, while the combinations of vasopressin and norepinephrine, epinephrine and norepinephrine, and terlipressin, dobutamine, and norepinephrine were used in 1 trial.

\section{Risk of bias}

As shown in Fig. 2, the most common risk was blinding of participants and personnel almost with one fourth of trials considered to be at high risk for bias. This was probably explained by the difficulty of blinding personnel who were performing 1 or more different medications in each patient. The lowest risk was random sequence generation, with exceeding $80 \%$ of trials considered to be at low risk for bias. The risk for random sequence generation, incomplete outcome data, selective reporting, and other bias was considered to be at high risk in non-trials. The details for the risk of bias were presented in (Additional file 1: Table S2). In summary, 24 trials were considered to be at low risk, and 14 trials were considered to be at unclear risk, while 5 trials were considered to be at high risk.

\section{Synthesis of results}

Heterogeneity assessment, network geometry, SUCRA, forest plot, contribution plot, inconsistency analyses, and publication bias analyses were presented for most outcomes.

\section{Mortality}

\section{Twenty-eight-day mortality}

A total of 24 trials with 5150 patients, which were compared to 15 treatments, were included in this analysis. There was no heterogeneity among the trials reporting 28 -day mortality $\left(X^{2}=12.46, P=0.96, I^{2}=0\right)$. The network geometry was shown in Fig. 3. Norepinephrine was used most frequently to assess 28 -day mortality. The direct comparison between norepinephrine and dopamine

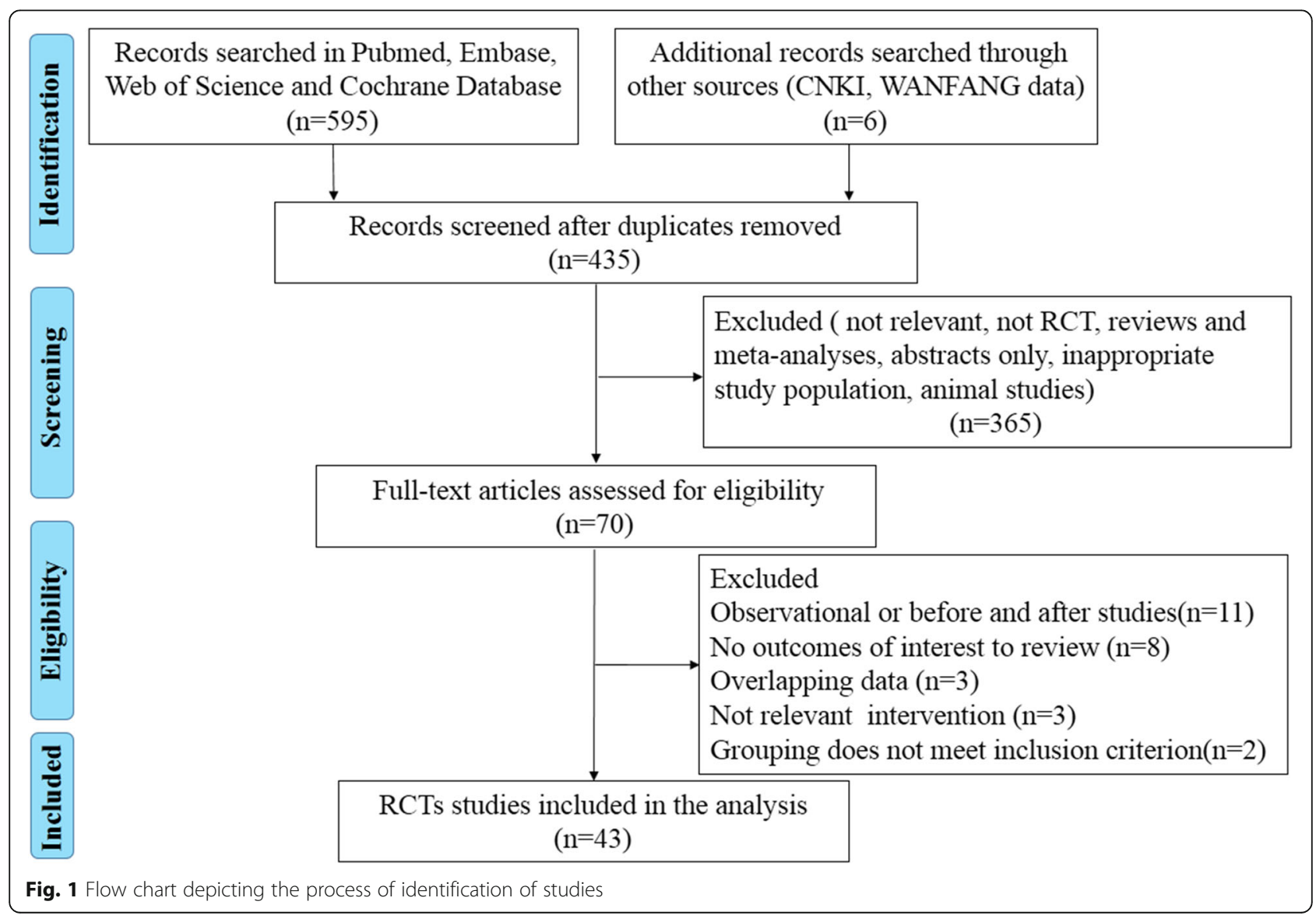


Table 1 Studies designs of included randomized controlled trials

\begin{tabular}{|c|c|c|c|c|c|c|c|c|}
\hline ID & Source & Country & Setting & $\begin{array}{l}\text { Male/ } \\
\text { female }\end{array}$ & Treatment 1 & Treatment 2 & Treatment 3 & Primary outcome \\
\hline 1 & $\begin{array}{l}\text { Martin et al. } \\
1993[32]\end{array}$ & France & SC & $24 / 8$ & Dopamine & Norepinephrine & & Hemodynamics status \\
\hline 2 & $\begin{array}{l}\text { Marik and } \\
\text { Mohedin } 1994 \\
\text { [33] }\end{array}$ & USA & SC & $11 / 9$ & Norepinephrine & Dopamine & & $\begin{array}{l}\text { Systemic and splanchnic oxygen } \\
\text { utilization }\end{array}$ \\
\hline 3 & $\begin{array}{l}\text { Levy et al. } 1997 \\
\text { [34] }\end{array}$ & France & SC & $21 / 9$ & Epinephrine & $\begin{array}{l}\text { Norepinephrine/ } \\
\text { dobutamine }\end{array}$ & & $\begin{array}{l}\text { Hemodynamics, lactate metabolism, } \\
\text { and gastric tonometric variables }\end{array}$ \\
\hline 4 & $\begin{array}{l}\text { Malay et al. } 1999 \\
\text { [35] }\end{array}$ & USA & SC & $8 / 2$ & Vasopressin & Placebo & & Arterial pressure \\
\hline 5 & $\begin{array}{l}\text { Kern et al. } 2001 \\
{[36]}\end{array}$ & Germany & SC & NA & Enoximone & Dobutamine & & Hepatosplanchnic function \\
\hline 6 & $\begin{array}{l}\text { Seguin et al. } \\
2002[37]\end{array}$ & France & SC & $12 / 10$ & Epinephrine & $\begin{array}{l}\text { Norepinephrine/ } \\
\text { dobutamine }\end{array}$ & & $\begin{array}{l}\text { Systemic and pulmonary } \\
\text { hemodynamics }\end{array}$ \\
\hline 7 & $\begin{array}{l}\text { Patel et al. } 2002 \\
\text { [38] }\end{array}$ & Canada & $M C$ & $18 / 6$ & Norepinephrine & Vasopressin & & Renal function \\
\hline 8 & $\begin{array}{l}\text { Dünser et al. } \\
2003 \text { [39] }\end{array}$ & Australia & SC & NA & $\begin{array}{l}\text { Arginine } \\
\text { vasopressin }\end{array}$ & Norepinephrine & & Differences in hemodynamics \\
\hline 9 & $\begin{array}{l}\text { Morelli et al. } \\
2005[40]\end{array}$ & Italy & $M C$ & $21 / 7$ & Dobutamine & Levosimendan & & $\begin{array}{l}\text { Systemic and regional } \\
\text { hemodynamics }\end{array}$ \\
\hline 10 & $\begin{array}{l}\text { Albanèse et al. } \\
2005 \text { [41] }\end{array}$ & France & SC & $13 / 7$ & Norepinephrine & Terlipressin & & MAP \\
\hline 11 & $\begin{array}{l}\text { Luckner et al. } \\
2006[42]\end{array}$ & Australia & SC & $11 / 7$ & $\begin{array}{l}\text { Vasopressin/ } \\
\text { norepinephrine }\end{array}$ & Norepinephrine & & Cutaneous vascular reactivity \\
\hline 12 & $\begin{array}{l}\text { Seguin et al. } \\
2006 \text { [43] }\end{array}$ & France & SC & $17 / 5$ & $\begin{array}{l}\text { Dopexamine/ } \\
\text { norepinephrine }\end{array}$ & Epinephrine & & Gastric perfusion \\
\hline 13 & $\begin{array}{l}\text { Schmoelz et al. } \\
2006[44]\end{array}$ & Germany & SC & $35 / 26$ & Dopexamine & Dopamine & Placebo & Systemic and renal effects \\
\hline 14 & $\begin{array}{l}\text { Lauzier et al. } \\
2006 \text { [45] }\end{array}$ & $\begin{array}{l}\text { Canada, } \\
\text { France }\end{array}$ & $M C$ & $14 / 9$ & Vasopressin & Norepinephrine & & $\begin{array}{l}\text { Hemodynamic parameters and } \\
\text { SOFA score }\end{array}$ \\
\hline 15 & $\begin{array}{l}\text { Mathur et al. } \\
2007 \text { [46] }\end{array}$ & India & SC & $32 / 18$ & Dopamine & Norepinephrine & & Hemodynamic parameters \\
\hline 16 & $\begin{array}{l}\text { Annane et al. } \\
2007 \text { [47] }\end{array}$ & France & MC & $\begin{array}{l}202 / \\
128\end{array}$ & Epinephrine & $\begin{array}{l}\text { Norepinephrine/ } \\
\text { dobutamine }\end{array}$ & & 28-day all-cause mortality \\
\hline 17 & $\begin{array}{l}\text { Myburgh et al. } \\
2008[48]\end{array}$ & Australia & $M C$ & $\begin{array}{l}167 / \\
110\end{array}$ & Epinephrine & Norepinephrine & & $\begin{array}{l}\text { The time taken to achieve a } \\
\text { clinician-prescribed MAP goal }\end{array}$ \\
\hline 18 & $\begin{array}{l}\text { Morelli et al. } \\
2008 \text { [49] }\end{array}$ & Italy & SC & $43 / 16$ & Norepinephrine & $\begin{array}{l}\text { Terlipressin/ } \\
\text { norepinephrine }\end{array}$ & $\begin{array}{l}\text { Terlipressin/ } \\
\text { dobutamine/ } \\
\text { norepinephrine }\end{array}$ & $\begin{array}{l}\text { Systemic, pulmonary, and regional } \\
\text { hemodynamic measurements and } \\
\text { blood gases }\end{array}$ \\
\hline 19 & $\begin{array}{l}\text { Morelli et al. } \\
2008[50]\end{array}$ & Italy & SC & $21 / 11$ & Norepinephrine & Phenylephrine & & Hemodynamic parameters \\
\hline 20 & $\begin{array}{l}\text { Russell et al. } \\
2008 \text { [51] }\end{array}$ & $\begin{array}{l}\text { Canada, } \\
\text { Australia, } \\
\text { USA }\end{array}$ & $M C$ & $\begin{array}{l}475 / \\
304\end{array}$ & Norepinephrine & Vasopressin & & Death from any cause \\
\hline 21 & $\begin{array}{l}\text { Morelli et al. } \\
2009[52]\end{array}$ & Italy & SC & $21 / 9$ & Terlipressin & Norepinephrine & Vasopressin & $\begin{array}{l}\text { Systemic and regional } \\
\text { hemodynamics }\end{array}$ \\
\hline 22 & $\begin{array}{l}\text { Alhashemi et al. } \\
2009 \text { [53] }\end{array}$ & $\begin{array}{l}\text { Saudi } \\
\text { Arabia }\end{array}$ & SC & NA & Levosimendan & Dobutamine & & $\begin{array}{l}\text { Central venous saturation (ScvO2) } \\
\text { and serum lactate }\end{array}$ \\
\hline 23 & $\begin{array}{l}\text { De Backer et al. } \\
2010 \text { [54] }\end{array}$ & $\begin{array}{l}\text { Belgium, } \\
\text { Austria, } \\
\text { Spain }\end{array}$ & $M C$ & $\begin{array}{l}956 / \\
723\end{array}$ & Dopamine & Norepinephrine & & The rate of death at 28 days \\
\hline 24 & $\begin{array}{l}\text { Jain and Singh } \\
2010[55]\end{array}$ & India & SC & $28 / 26$ & Norepinephrine & Phenylephrine & & Hemodynamic parameters \\
\hline 25 & $\begin{array}{l}\text { Patel et al. } 2010 \\
\text { [56] }\end{array}$ & USA & SC & $\begin{array}{l}116 / \\
136\end{array}$ & Dopamine & Norepinephrine & & All-cause 28-day mortality \\
\hline
\end{tabular}


Table 1 Studies designs of included randomized controlled trials (Continued)

\begin{tabular}{|c|c|c|c|c|c|c|c|c|}
\hline $\mathrm{ID}$ & Source & Country & Setting & $\begin{array}{l}\text { Male/ } \\
\text { female }\end{array}$ & Treatment 1 & Treatment 2 & Treatment 3 & Primary outcome \\
\hline 26 & $\begin{array}{l}\text { Morelli et al. } \\
2010[57]\end{array}$ & Italy & SC & $27 / 13$ & Levosimendan & Dobutamine & & $\begin{array}{l}\text { Systemic and microvascular } \\
\text { hemodynamics }\end{array}$ \\
\hline 27 & $\begin{array}{l}\text { Morelli et al. } \\
2011[58]\end{array}$ & Italy & SC & $37 / 23$ & Terlipressin & $\begin{array}{l}\text { Arginine } \\
\text { vasopressin }\end{array}$ & Control & Microcirculatory perfusion \\
\hline 28 & $\begin{array}{l}\text { Han et al. } 2012 \\
\text { [59] }\end{array}$ & China & MC & $99 / 40$ & Pituitrin & Norepinephrine & & The rate of death at 28 days \\
\hline 29 & $\begin{array}{l}\text { Mahmoud and } \\
\text { Ammar } 2012 \\
{[60]}\end{array}$ & Egypt & SC & $31 / 29$ & $\begin{array}{l}\text { Norepinephrine/ } \\
\text { dobutamine }\end{array}$ & $\begin{array}{l}\text { Norepinephrine/ } \\
\text { epinephrine }\end{array}$ & & $\begin{array}{l}\text { SOFA score and cardiovascular } \\
\text { effects }\end{array}$ \\
\hline 30 & $\begin{array}{l}\text { Memis et al. } \\
2012[61]\end{array}$ & Turkey & SC & $16 / 14$ & Dobutamine & Levosimendan & & Regional blood flow \\
\hline 31 & $\begin{array}{l}\text { Mehta et al. } \\
2013 \text { [62] }\end{array}$ & Canada & MC & $85 / 36$ & Norepinephrine & Vasopressin & & $\begin{array}{l}\text { Cardiac biomarkers and } \\
\text { electrocardiograms }\end{array}$ \\
\hline 32 & $\begin{array}{l}\text { Hua et al. } 2013 \\
\text { [63] }\end{array}$ & China & SC & $18 / 14$ & Terlipressin & Dopamine & & $\begin{array}{l}\text { Hemodynamics and oxygenation } \\
\text { variables }\end{array}$ \\
\hline 33 & $\begin{array}{l}\text { Fang and Dong } \\
2014 \text { [64] }\end{array}$ & China & SC & $27 / 9$ & Dobutamine & Levosimendan & & $\begin{array}{l}\text { Hemodynamics and cardiac } \\
\text { function }\end{array}$ \\
\hline 34 & $\begin{array}{l}\text { Torraco et al. } \\
2014[65]\end{array}$ & Italy & SC & $19 / 7$ & Levosimendan & Control & & Mitochondrial function \\
\hline 35 & $\begin{array}{l}\text { Gordon et al. } \\
2016[66]\end{array}$ & UK & MC & $\begin{array}{l}238 / \\
171\end{array}$ & Vasopressin & Norepinephrine & & $\begin{array}{l}\text { Kidney failure-free days during the } \\
\text { 28-day period }\end{array}$ \\
\hline 36 & $\begin{array}{l}\text { Xiao et al. } 2016 \\
\text { [67] }\end{array}$ & China & SC & $22 / 10$ & Norepinephrine & $\begin{array}{l}\text { Terlipressin/ } \\
\text { norepinephrine }\end{array}$ & & $\begin{array}{l}\text { Tissue blood flow and organ } \\
\text { function }\end{array}$ \\
\hline 37 & $\begin{array}{l}\text { Gordon et al. } \\
2016[68]\end{array}$ & UK & MC & $\begin{array}{l}289 / \\
226\end{array}$ & Levosimendan & Placebo & & Mean daily SOFA score \\
\hline 38 & $\begin{array}{l}\text { Meng et al. } 2016 \\
\text { [69] }\end{array}$ & China & SC & $24 / 14$ & Levosimendan & Dobutamine & & $\begin{array}{l}\text { Biomarkers of myocardial injury } \\
\text { and systemic hemodynamics }\end{array}$ \\
\hline 39 & $\begin{array}{l}\text { Barzegar et al. } \\
2016 \text { [70] }\end{array}$ & Iran & SC & 19/11 & Norepinephrine & Vasopressin & & Lactate level and lactate clearance \\
\hline 40 & $\begin{array}{l}\text { Choudhury et al. } \\
2016 \text { [71] }\end{array}$ & India & SC & $69 / 15$ & Terlipressin & Noradrenaline & & Hemodynamics \\
\hline 41 & $\begin{array}{l}\text { Chen et al. } 2017 \\
\text { [72] }\end{array}$ & China & SC & $29 / 28$ & Norepinephrine & Terlipressin & & $\begin{array}{l}\text { Hemodynamics, volume } \\
\text { responsiveness }\end{array}$ \\
\hline 42 & $\begin{array}{l}\text { Hajjej et al. } 2017 \\
\text { [73] }\end{array}$ & Tunisia & SC & $17 / 3$ & Levosimendan & Placebo & & Cellular metabolism \\
\hline 43 & $\begin{array}{l}\text { Russell et al. } \\
2017 \text { [8] }\end{array}$ & $\begin{array}{l}\text { Belgium, } \\
\text { Denmark, } \\
\text { USA }\end{array}$ & MC & $27 / 21$ & Selepressin & Placebo & & $\begin{array}{l}\text { Stabilization of MAP as determinec } \\
\text { by the proportion of patients } \\
\text { maintaining a MAP }>60 \mathrm{mmHg}\end{array}$ \\
\hline
\end{tabular}

was most frequent. Treatments ranking based on SUCRA values, which were shown in Fig. 4, from largest to smallest, were as follows: NE/DB $85.9 \%$, TP $75.1 \%$, NE/EP 74.6\%, PI 74.1\%, EP 72.5\%, VP 66.1\%, NE 59.8\%, PE 53.0\%, DA 42.1\%, DX 38.2\%, SP 27.0\%, PA 24.3\%, EX $22.8 \%$, LE $21.5 \%$, and DB $13.3 \%$. The forest plot for direct comparison was shown in Fig. 5. The funnel plot for 28-day mortality was presented in Fig. 6. The evidence of publication bias for RR of 28-day mortality was not detected. The contribution plot, inconsistency analysis, and forest plot for all comparisons were presented in Additional file 1.

\section{ICU mortality}

A total of 18 trials with 1466 patients, which were compared to 11 treatments, were included in this analysis. No heterogeneity was found among trials that reported ICU mortality $\left(\chi^{2}=13.75, P=0.68, I^{2}=0 \%\right)$. Similarly, norepinephrine was used most frequently to assess ICU mortality. The direct comparison between norepinephrine and vasopressin was the most frequent. Treatments ranking based on SUCRA values, from largest to smallest, were as follows: TP/NE $86.4 \%$, TP $80.3 \%$, TP/DB/ NE 65.7\%, VP/NE 62.8\%, NE 57.4\%, VP 56.5\%, PE 48.4\%, DA $33.0 \%$, PA $27.5 \%$, LE 22.1\%, and DB 9.9\%. 


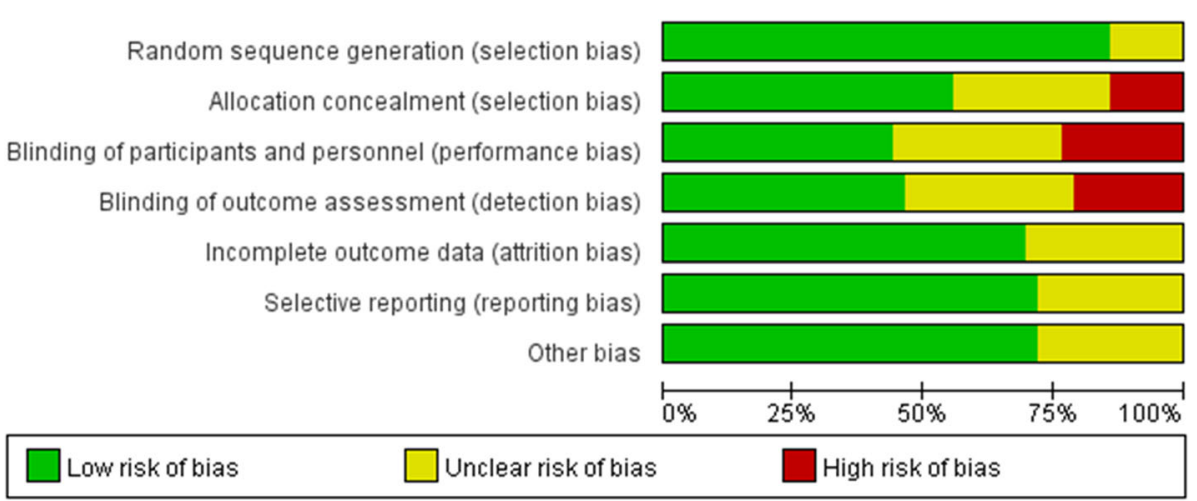

Fig. 2 Risk of bias assessment: overall risk of bias for all included trials

\section{Secondary outcomes} ICU length of stay

A total of 12 trials with 3541 patients, which were compared to 7 interventions, were included in this analysis. Significant heterogeneity was found among trials reporting ICU length of stay $\left(\chi^{2}=98.73, P<0.01, I^{2}=89 \%\right)$. After omitting 1 trial (De Backer et al. 2010), the $I^{2}$ value was reduced to $66 \%$. Norepinephrine was most frequently used to assess ICU LOS. The direct comparison between norepinephrine and dopamine was most frequent. Treatments ranking based on SUCRA values, from largest to smallest, were as follows: TP $76.9 \%$, DA
68.1\%, PE 59.7\%, NE 49.1\%, TP/DB/NE 41.7\%, TP/NE $33.7 \%$, and VP $20.9 \%$.

\section{Hospital LOS}

A total of 7 trials with 3003 patients, which were compared to 4 interventions, were included in this analysis. There was a significant heterogeneity among trials for reporting hospital LOS $\left(\chi^{2}=17.36, P=0.008, I^{2}=65 \%\right)$. After omitting 1 study (Mehta $S$ et al. 2013), no heterogeneity was found around these trials $\left(\chi^{2}=2.19, P=0.82\right.$, $\left.I^{2}=0 \%\right)$. Norepinephrine was most frequently used to assess hospital LOS. The direct comparison between

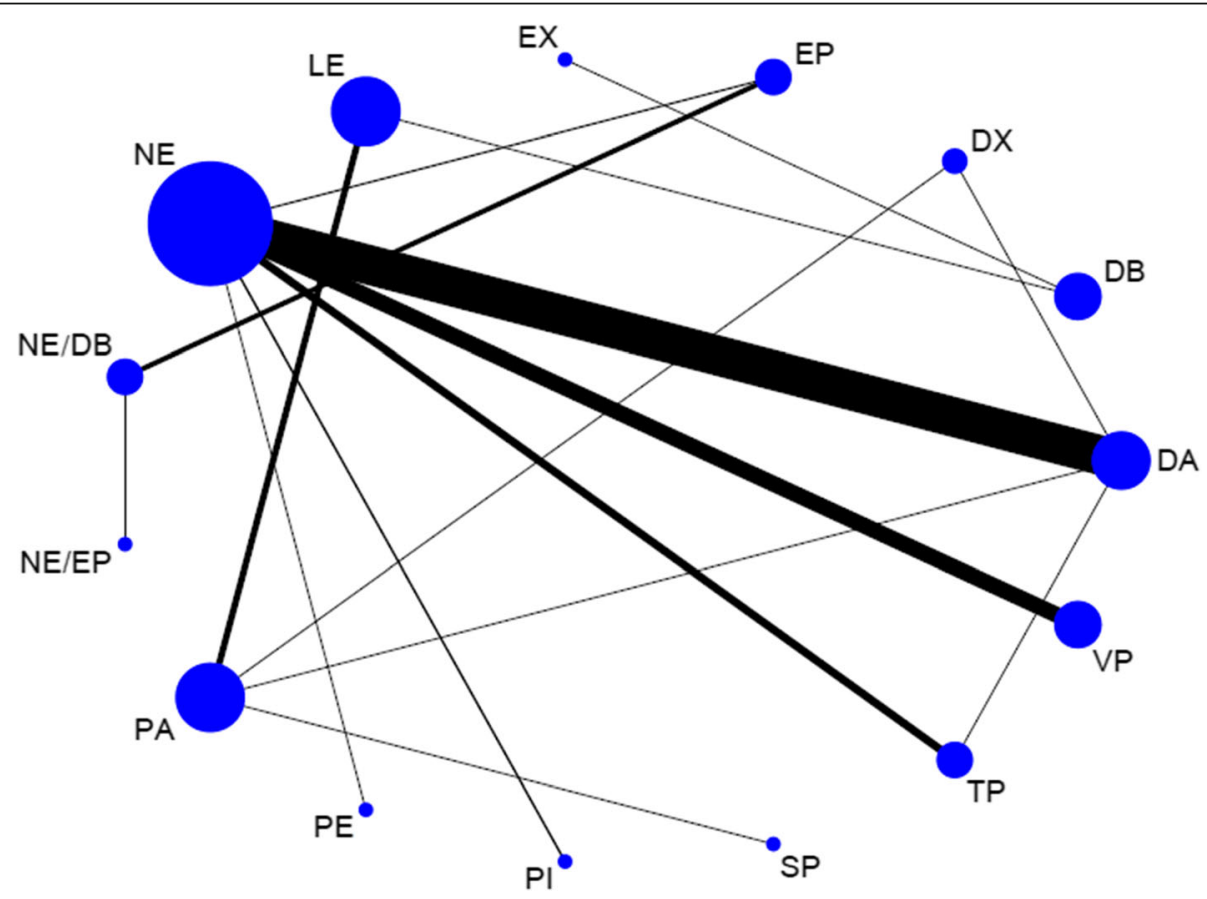

Fig. 3 Network geometry. Network of all the included treatment agents for evaluating mortality. The size of the nodes was proportional to the number of patients randomized to each modality and thickness of the lines to the number of direct comparisons. For example, the circle area for NE was the largest, and the edge between NE and DA was much wider, indicating that the number of studies on NE was the highest, and the direct comparisons between NE and DA were the most common in the existed literatures 


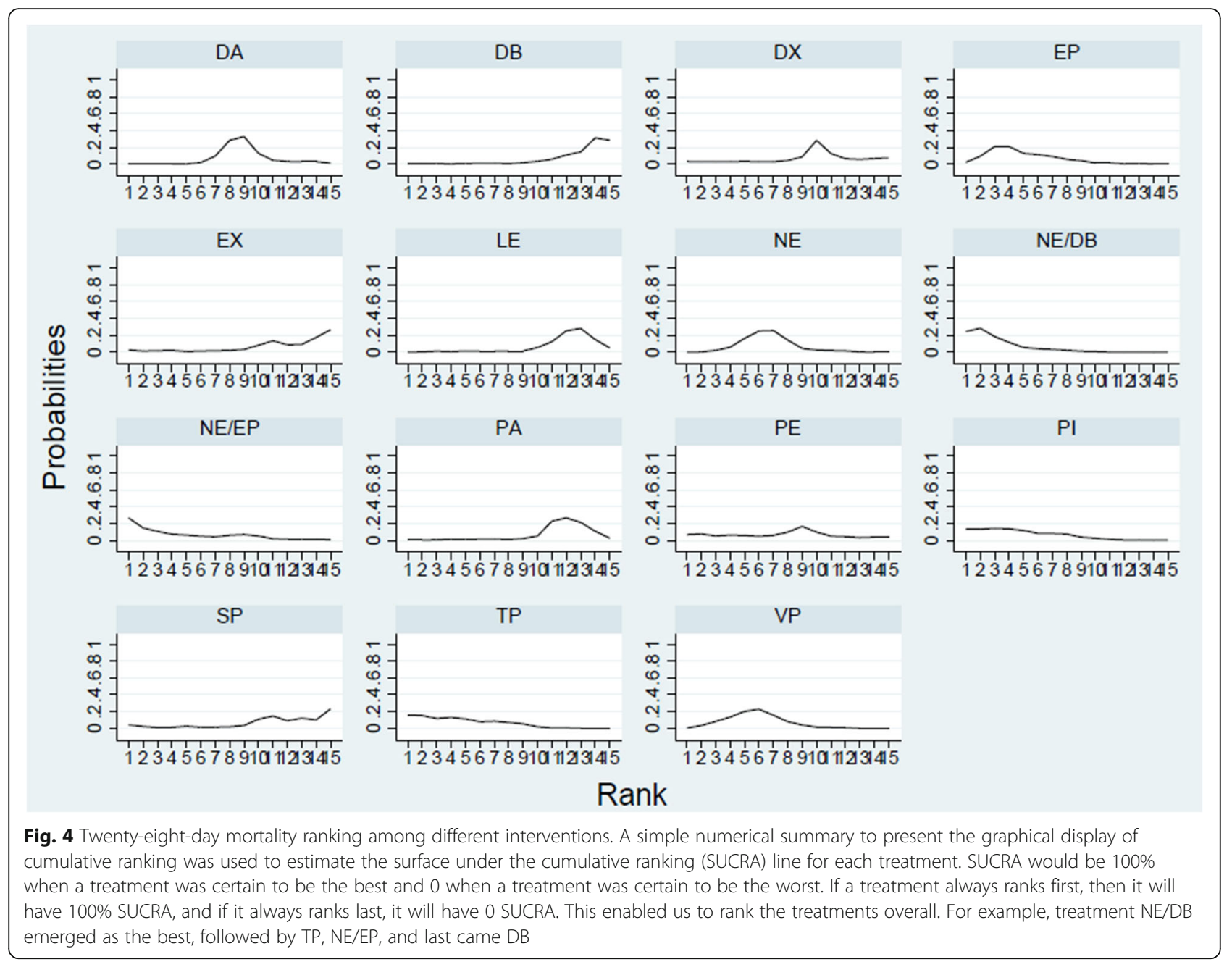

norepinephrine and dopamine was most frequent. Treatments ranking based on SUCRA values, from largest to smallest, were as follows: VP $82.7 \%$ (95\%CI, 79.27 to 83.48), DA $49.8 \%$, TP $46.2 \%$, and NE $21.3 \%$.

\section{Adverse events \\ Myocardial infarction}

A total of 7 trials with 3793 patients, which were compared to 8 treatments, reported the incidence of myocardial infarction. The most common incidence was reported with NE/EP 3.33\% ( $n=1$ of 30 ), followed by EP $3.11 \%(n=5$ of 161$)$, and then VP $3.10 \%(n=19$ of 613$)$, NE $3.03 \%(n=43$ of 1417$)$, DA $2.21 \%(n=19$ of 858$)$, NE/DB $2.01 \%(n=4$ of 199$)$, LE $1.16 \%(n=3$ of 258$)$, and PA $0.39 \%(n=1$ of 257$)$.

\section{Arrhythmia}

A total of 7 trials with 4022 patients, which were compared to 8 treatments, reported the incidence of arrhythmia. The most common incidence was reported with DA $26.01 \%$ ( $n=258$ of 992), followed by EP $22.98 \%$
( $n=37$ of 161), and then NE/DB 20.60\% ( $n=41$ of 199), NE/EP $20.0 \%$ ( $n=6$ of 30$)$, NE $8.33 \%(n=127$ of 1525$)$, LE $5.81 \%(n=15$ of 258$)$, PA $2.33 \%$ ( $n=6$ of 257$)$, and VP $1.67 \%(n=10$ of 600$)$.

\section{Peripheral ischemia}

The limb ischemia, skin ischemia, mesenteric ischemia, and digital ischemia contributed to peripheral ischemia. A total of 5 trials with 3255 patients, which were compared to 6 treatments, reported the incidence of peripheral ischemia. The most common incidence was reported with NE/EP $10.0 \%$ ( $n=3$ of 30 ), followed by DA $6.53 \%(n=56$ of 858$)$, and then NE/DB $4.02 \%(n=8$ of 199$)$, VP $4.0 \%(n=24$ of 600$)$, NE $3.13 \%(n=44$ of 1407), and EP $1.24 \%$ ( $n=2$ of 161).

\section{GRADE evaluation}

As shown in Table 2, GRADE evaluations were conducted for 28-day mortality. The other outcomes of 


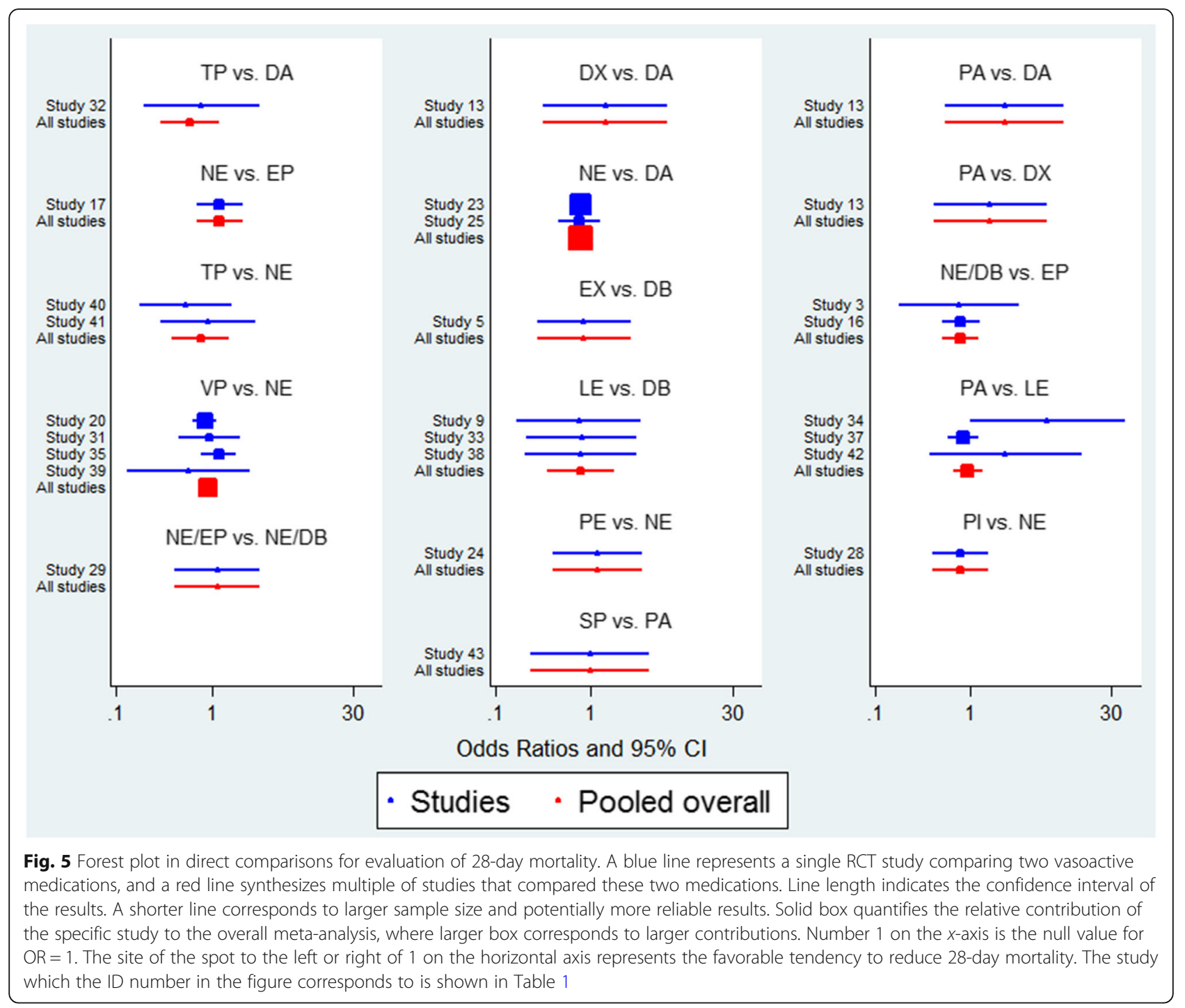

GRADE evaluations probably had equivalent or worse quality.

\section{Discussion}

In this multiple-treatments meta-analysis of randomized controlled trials for septic shock, a comprehensive literature search was performed with no restriction for publication date, to ensure maximum coverage of existing trials. This multiple-treatments meta-analysis showed that the administration of norepinephrine combined with dobutamine may be associated with lower 28-day mortality among septic shock patients compared to other vasoactive medications. In addition, norepinephrine plus terlipressin was associated with decreased ICU mortality compared to other medications. Furthermore, terlipressin and vasopressin were associated with reduced length of stay in ICU and hospital, respectively.
There were eight systematic reviews and meta-analyses that evaluated the effects of vasoactive medications among patients with septic shock [9, 10, 22-27]. This multiple-treatments meta-analysis is the first one that altogether considered mortality, length of stay, and adverse events as outcomes. Findings in this study with those studies were compared in Table 3. There were four pairwise meta-analyses that compared the efficacy between two interventions [9, 10, 22, 23] and four network meta-analyses that compared the efficacy among multiple interventions [24-27]. Different from the existing studies, our research had some remarkable characteristics. Firstly, the previous conventional meta-analysis usually focused on pairwise comparisons of two therapeutic measures, but this study is a network meta-analysis, which was able to construct two or more interventions into a network structure, enabling computation of relative effectiveness from both direct one-to-one and 


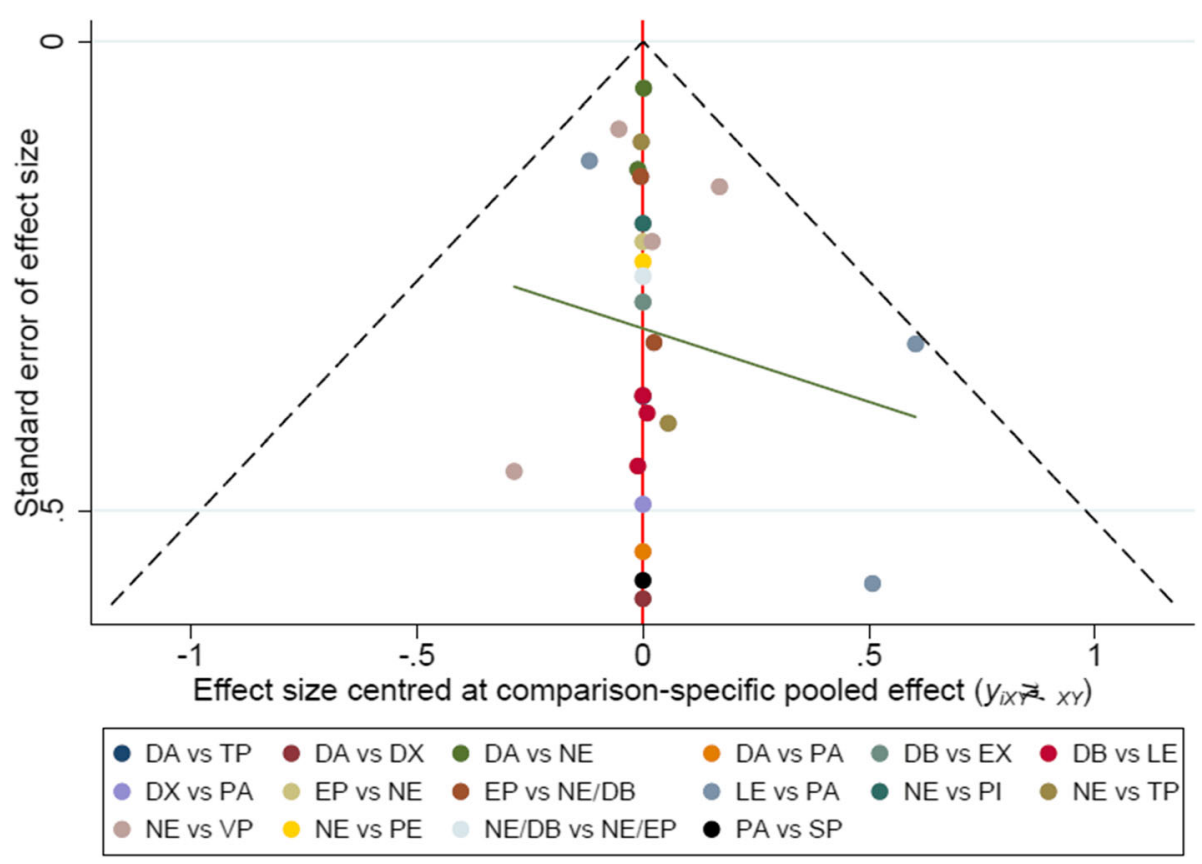

Fig. 6 Funnel plot for 28-day mortality, with a complex evidence network including 16 sets of head-to-head randomized trials: treatment DA versus TP, DA versus DX, DA versus NE, DA versus $P A, D B$ versus EX, DB versus $L E, D X$ versus $P A, E P$ versus NE, EP versus NE/DB, $L E$ versus $P A, N E$ versus PI, NE versus TP, NE versus VP, NE versus PE, NE/DB versus NE/EP, and PA versus SP. Single markers represented the individual primary studies, while the dashed vertical line showed the summary effect estimate, and the dashed oblique lines showed the $95 \%$ confidence intervals at varying degree of precision

Table 2 GRADE evaluation for 28-day mortality

\begin{tabular}{llll}
\hline Comparisons & Number of comparisons & Contribution to the network (\%) & Confidence \\
\hline DA vs. DX & 1 & 4.0 & High \\
DA vs. NE & 2 & 4.3 & High \\
DA vs. PA & 1 & 2.4 & High \\
DA vs. TP & 1 & 10.1 & Moderate \\
DB vs. EX & 1 & 0.7 & High \\
DB vs. LE & 3 & 0.7 & Moderate \\
DX vs. PA & 1 & 5.1 & High \\
NE vs. EP & 1 & 17.9 & High \\
EP vs. NE/DB & 2 & 11.4 & Moderate \\
LE vs. PA & 3 & 5.3 & High \\
NE/DB vs. NE/EP & 1 & 7.3 & High \\
NE vs. PE & 1 & 4.2 & Low \\
NE vs. PI & 1 & 6.6 & Moderate \\
NE vs. TP & 2 & 9.1 & Low \\
NE vs. VP & 4 & 6.8 & High \\
SP vs. PA & 1 & 4.1 & High \\
\hline The & non & &
\end{tabular}

The contribution represents the proportion of each comparison in the whole network meta-analysis. Higher proportion indicates more contribution to the NMA. GRADE classifies the overall quality of a body of evidence for each outcome across studies into four levels: high, moderate, low, and very low. The rating reflects the extent of the confidence in the estimates of intervention's effects 
Table 3 Comparison of our study with relevant studies

\begin{tabular}{|c|c|c|c|c|c|c|c|}
\hline Author & Publication date & Type & Number of studies & Number of included patients & Number of inventions & SUCRA & Survive benefit \\
\hline This study & & NMA & 43 & 5767 & 17 & Yes & $\mathrm{NE} / \mathrm{DB}$ \\
\hline De Backer D & 2012 & MA & 6 & 1408 & 2 & - & NE \\
\hline Vasu TS & 2012 & MA & 6 & 2043 & 2 & - & NE \\
\hline Serpa Neto A & 2012 & MA & 9 & 998 & 2 & - & $\mathrm{VP}$ \\
\hline Avni T & 2015 & NMA & 32 & 3544 & 5 & No & NE \\
\hline Zhou F & 2015 & NMA & 21 & 3819 & 11 & No & NE \\
\hline Nagendran M & 2016 & NMA & 13 & 3146 & 9 & No & VP \\
\hline Wang B & 2017 & MA & 10 & 816 & 4 & - & None \\
\hline Belletti A & 2017 & NMA & 33 & 3470 & 16 & No & Inodilators \\
\hline
\end{tabular}

indirect comparison with multiple interventions that were not evaluated in a direct assessment. Secondly, all the published NMA studies did not use the SUCRA values to determine the hierarchy of interventions for outcomes. It is the first time that the effectiveness of these vasoactive medications was ranked objectively according to their SUCRA values. The SUCRA values showed the percentage of effectiveness for each intervention compared to a hypothetical optimal intervention, which was considered the best without uncertainty [18, 28-30]. Consequently, NMA was able to provide the highest level of evidence for clinical guidelines. Thirdly, previous studies did not include the latest RCTs, due to the time of publication and sample sizes were not large enough for accurate assessment of these treatments. Missing studies and an inadequate number of patients could substantially impact the outcome of NMA. In this NMA, a comprehensive assessment of the various therapeutic interventions with higher precision and larger sample sizes was performed.

This multiple-treatments meta-analysis included a total of 17 different vasoactive interventions, which were used frequently by clinicians to treat patients with septic shock for improving their hemodynamic status. Bayesian NMA was used to estimate the comparative efficacy of the combined use of vasoactive agents, aiming to identify the most preferable regimen to improve blood pressure and heart function in the clinical setting. Meanwhile, more evidence-based information on selection of the most optimal treatment for septic shock were attempted to present. The SUCRA values were used to identify which vasoactive medications were associated with lower mortality and hospital stay among patients with septic shock. For an overall assessment of the best therapeutic option, a cumulative SUCRA score was derived by summing the individual SUCRA values for each endpoint for all 17 interventions. Taking all 4 key clinical endpoints into consideration, the 3 best options in the order of final ranking were as follows: norepinephrine plus dobutamine, norepinephrine plus epinephrine, and terlipressin.
Norepinephrine has been recognized as the first-line treatment for achieving hemodynamic goals for septic shock in international guidelines [1]. When the administration of norepinephrine alone was not able to improve the hemodynamic status, other vasoactive medications would be added. According to the results of this network meta-analysis, dobutamine is superior to other vasoactive medications in reducing 28-day mortality when combined with norepinephrine. Nevertheless, there is a potential risk when giving dobutamine to septic shock patients with normal cardiac function. As one of the inotropic medications, dobutamine may cause atrial fibrillation, multifocal atrial tachycardia, ventricular tachycardia, and fibrillation. Administration of vasopressor plus inotrope with high $\beta$-adrenergic component may contribute to a worse outcome and increase the incidence of arrhythmias [31]. It is essential to therefore identify patients who may benefit from dobutamine. Patients with a low cardiac output due to impaired contractility may probably benefit from dobutamine. For these patients, it is an option to add dobutamine when norepinephrine alone cannot improve the hemodynamic status. The dose of dobutamine should be adjusted according to the patients' response. If adverse events occur, dobutamine should be discontinued immediately.

This study still had some limitations. Firstly, by the nature of meta-analysis in general, the results of this paper were dependent on the quality of available studies. Some included studies were small-scale single-centered trials. The results and conclusions should therefore be interpreted with caution, because of relatively small sample sizes. Secondly, some included studies did not really randomized patients to receive the vasoactive medications in a sustained manner. This was a potential factor that may have influenced the results of this network meta-analysis. Thirdly, four studies were included to compare the effect on mortality between norepinephrine plus dobutamine and other vasoactive medications. Majority of these studies did not use dobutamine according to the change of cardiac function, which probably varied the results. Fourthly, NMA included both direct and indirect comparisons, which contributed to the reduced statistical power and uncertainty 
on ranking results. More trials are thus expected to help accurately assess the clinical value for the combined use of vasoactive medications. Especially, direct comparisons between norepinephrine plus dobutamine and norepinephrine alone are needed to further confirm the conclusions and justify the combination of vasoactive medications for patients with septic shock. Fifthly, in some studies, more than one vasoactive medication was applied in both treatment and control groups during the trial, and the combination of different kinds of vasoactive medications without the same standard therapeutic drug-based protocol might complicate the analyses of the results.

\section{Conclusions}

The results from this network meta-analysis suggest that the use of norepinephrine plus dobutamine was associated with lower 28-day mortality for septic shock, especially among patients with low cardiac output.

\section{Additional file}

Additional file 1: Table S1. Study characteristics: management description of included randomized controlled trials. Table $\mathbf{S 2}$. Assessment of risk of bias. Figure S1-S3. Forest plot for the overall comparisons, contribution plot, and inconsistency analysis for 28-day mortality. Figure S4-S9. Network geometry, SUCRA, forest plot, contribution plot, inconsistency analysis, and funnel plot for ICU mortality. Figure S10-S15. Network geometry, SUCRA, forest plot, contribution plot, inconsistency analysis, and funnel plot for ICU length of stay. Figure S16-S21. Network geometry, SUCRA, forest plot, contribution plot, inconsistency analysis, and funnel plot for hospital length of stay. (PDF $1411 \mathrm{~kb}$ )

\section{Abbreviations}

CENTRAL: Cochrane Central Register for Controlled Trials; Cl: Confidence interval; DA: Dopamine; DB: Dobutamine; DX: Dopexamine; EP: Epinephrine; EX: Enoximone; GRADE: Grades of Recommendation, Assessment, Development and Evaluation; ICU: Intensive care unit; LE: Levosimendan; LOS: Length of stay: MAP: Mean arterial pressure; NE: Norepinephrine; NMA: Network meta-analysis; PA: Placebo; PE: Phenylephrine; PI: Pituitrin; RCTs: Randomized controlled trial studies; RR: Risk ratio; SMD: Standardized mean difference; SP: Selepressin; SUCRA: Surface under the cumulative ranking curve; TP: Terlipressin; VP: Vasopressin

\section{Acknowledgements}

The authors would like to thank Linfeng Dai, Yan Zhuang, and Haidong Zhang from the Affiliated Hospital of Nanjing University of Chinese Medicine for their help in statistics.

\section{Funding}

The work was supported by the National Natural Science Fund of China $(81704048,81503536)$ and Project of Jiangsu Provincial Administration of Chinese Medicine (YB2017015).

\section{Availability of data and materials}

All data generated or analyzed during the present study are included in this published article and its supplementary information files.

\section{Authors' contributions}

$L C$ and JY contributed equally to the manuscript. LC and JY conceived the study and drafted the manuscript. STH analyzed the data. QHC, MQC, and HJ did the literature search and the acquisition of data. $J L$ conceived and designed the study, revised the manuscript, and approved the final version of the manuscript. All authors read and approved the final manuscript.

\section{Ethics approval and consent to participate}

The study protocol was registered in the International Prospective Register of Systematic Reviews (CRD42018090437)

\section{Consent for publication}

We waived the necessity to obtain consent for publication because this study was a network meta-analysis.

\section{Competing interests}

The authors declare that they have no competing interests.

\section{Publisher's Note}

Springer Nature remains neutral with regard to jurisdictional claims in published maps and institutional affiliations.

\section{Author details}

1Department of Intensive Care Unit, Affiliated Hospital of Nanjing University of Chinese Medicine, 155 Hanzhong Road, Nanjing 210029, China. ${ }^{2}$ Key Laboratory for Metabolic Diseases in Chinese Medicine, First Clinical Medical College, Nanjing University of Chinese Medicine, 138 Xianlin Avenue, Nanjing 210013, China. ${ }^{3}$ Department of Center of Gastrointestinal Endoscopy, Affiliated Hospital of Nanjing University of Chinese Medicine, 155 Hanzhong Road, Nanjing 210029, China.

Received: 3 October 2018 Accepted: 9 April 2019

Published online: 14 May 2019

\section{References}

1. Seymour CW, Liu VX, Iwashyna TJ, Brunkhorst FM, Rea TD, Scherag A, et al. Assessment of clinical criteria for sepsis: for the Third International Consensus Definitions for Sepsis and Septic Shock (Sepsis-3). JAMA. 2016; 315:762-74

2. Singer M, Deutschman CS, Seymour CW, Shankar-Hari M, Annane D, Bauer $M$, et al. The Third International Consensus Definitions for Sepsis and Septic Shock (Sepsis-3). JAMA. 2016;315:801-10.

3. Annane D, Aegerter P, Jars-Guincestre MC, Guidet B, CUB-Réa Network. Current epidemiology of septic shock: the CUB-Réa Network. Am J Respir Crit Care Med. 2003;168:165-72.

4. Landry DW, Oliver JA. The pathogenesis of vasodilatory shock. N Engl J Med. 2001;345:588-95.

5. Machado FR, Cavalcanti AB, Bozza FA, Ferreira EM, Angotti Carrara FS, Sousa $J \mathrm{~L}$, et al. The epidemiology of sepsis in Brazilian intensive care units (the Sepsis PREvalence Assessment Database, SPREAD): an observational study. Lancet Infect Dis. 2017:17:1180-9.

6. Vincent JL, De Backer D. Circulatory shock. N Engl J Med. 2013;369:1726-34.

7. Rhodes A, Evans LE, Alhazzani W, Levy MM, Antonelli M, Ferrer R, et al. Surviving Sepsis Campaign: International Guidelines for Management of Sepsis and Septic Shock: 2016. Intensive Care Med. 2017:43:304-77.

8. Russell JA, Vincent JL, Kjølbye AL, Olsson H, Blemings A, Spapen H, et al. Selepressin, a novel selective vasopressin V1A agonist, is an effective. substitute for norepinephrine in a phase lla randomized, placebo-controlled trial in septic shock patients. Crit Care. 2017:21:213.

9. De Backer D, Aldecoa C, Njimi H, Vincent JL. Dopamine versus norepinephrine in the treatment of septic shock: a meta-analysis. Crit Care Med. 2012:40:725-30.

10. Vasu TS, Cavallazzi R, Hirani A, et al. Norepinephrine or dopamine for septic shock: systematic review of randomized clinical trials. J Intensive Care Med. 2012;27:172-8

11. Hutton B, Salanti G, Caldwell DM, Chaimani A, Schmid CH, Cameron C, et al. The PRISMA extension statement for reporting of systematic reviews incorporating network meta-analyses of health care interventions: checklist and explanations. Ann Intern Med. 2015;162:777-84.

12. Higgins JP, Green S. Cochrane handbook for systematic reviews of interventions version 5.1.0. London: Cochrane Collaboration; 2011

13. Higgins JP, Altman DG, Gotzsche PC, Jüni P, Moher D, Oxman AD, et al. The Cochrane Collaboration's tool for assessing risk of bias in randomised trials. BMJ. 2011;343:d5928

14. Hozo SP, Djulbegovic B, Hozo I. Estimating the mean and variance from the median, range, and the size of a sample. BMC Med Res Methodol. 2005;5:13.

15. DerSimonian R, Laird N. Meta-analysis in clinical trials. Control Clin Trials. 1986;7:177-88. 
16. Veroniki AA, Vasiliadis HS, Higgins JP, Salanti G. Evaluation of inconsistency in networks of interventions. Int J Epidemiol. 2013;42:332-45.

17. Higgins JP, Jackson D, Barrett JK, Lu G, Ades AE, White IR. Consistency and inconsistency in network meta-analysis: concepts and models for multi-arm studies. Res Synth Methods. 2012;3:98-110.

18. Salanti G. Indirect and mixed-treatment comparison, network, or multipletreatments meta-analysis: many names, many benefits, many concerns for the next generation evidence synthesis tool. Res Synth Methods. 2012;3:80-97.

19. Salanti G, Ades AE, loannidis JP. Graphical methods and numerical summaries for presenting results from multiple-treatment meta-analysis: an overview and tutorial. J Clin Epidemiol. 2011;64:163-71.

20. Salanti G, Del Giovane C, Chaimani A, Caldwell DM, Higgins JP. Evaluating the quality of evidence from a network meta-analysis. PLoS One. 2014;9: e99682.

21. Guyatt GH, Oxman AD, Vist GE, Kunz R, Falck-Ytter Y, Alonso-Coello P, et al. GRADE: an emerging consensus on rating quality of evidence and strength of recommendations. BMJ. 2008;336:924-6.

22. Serpa Neto A, Nassar AP, Cardoso SO, Manetta JA, Pereira VG, Espósito DC, et al. Vasopressin and terlipressin in adult vasodilatory shock: a systematic review and meta-analysis of nine randomized controlled trials. Crit Care. 2012:16:R154.

23. Avni T, Lador A, Lev S, Leibovici L, Paul M, Grossman A. Vasopressors for the treatment of septic shock: systematic review and meta-analysis. PLoS One. 2015;10:e0129305.

24. Zhou F, Mao Z, Zeng X, Kang H, Liu H, Pan L, et al. Vasopressors in septic shock: a systematic review and network meta-analysis. Ther Clin Risk Manag. 2015:11:1047-59.

25. Nagendran M, Maruthappu M, Gordon AC, Gurusamy KS. Comparative safety and efficacy of vasopressors for mortality in septic shock: a network meta-analysis. J Intensive Care Soc. 2016;17:136-45.

26. Wang B, Chen R, Guo X, Zhang W, Hu J, Gong Y, et al. Effects of levosimendan on mortality in patients with septic shock: systematic review with metaanalysis and trial sequential analysis. Oncotarget. 2017;8:100524-32.

27. Belletti A, Benedetto U, Biondi-Zoccai G, Leggieri C, Silvani P, Angelini GD, et al. The effect of vasoactive drugs on mortality in patients with severe sepsis and septic shock. A network meta-analysis of randomized trials. J Crit Care. 2017;37:91-8.

28. Tonin FS, Rotta I, Mendes AM, Pontarolo R. Network meta-analysis: a technique to gather evidence from direct and indirect comparisons. Pharm Pract (Granada). 2017;15:943.

29. Leucht S, Chaimani A, Cipriani AS, Davis JM, Furukawa TA, Salanti G, et al. Network meta-analyses should be the highest level of evidence in treatment guidelines. Eur Arch Psychiatry Clin Neurosci. 2016;266:477-80.

30. Terkawi AS, Mavridis D, Sessler DI, Nunemaker MS, Doais KS, Terkawi RS, et al. Pain management modalities after total knee arthroplasty: a network meta-analysis of 170 randomized controlled trials. Anesthesiology. 2017;126: 923-37.

31. Annane D, Ouanes-Besbes $L$, de Backer D, DU B, Gordon AC, Hernández G, et al. A global perspective on vasoactive agents in shock. Intensive Care Med. 2018;44:833-46.

32. Martin C, Papazian L, Perrin G, Saux P, Gouin F. Norepinephrine or dopamine for the treatment of hyperdynamic septic shock? Chest. 1993; 103(6):1826-31.

33. Marik PE, Mohedin M. The contrasting effects of dopamine and norepinephrine on systemic and splanchnic oxygen utilization in hyperdynamic sepsis. JAMA. 1994;272(17):1354-7.

34. Levy B, Bollaert PE, Charpentier C, Nace L, Audibert G, Bauer P, et al. Comparison of norepinephrine and dobutamine to epinephrine for hemodynamics, lactate metabolism, and gastric tonometric variables in septic shock: a prospective, randomized study. Intensive Care Med. 1997; 23(3):282-7.

35. Malay MB, Ashton RC Jr, Landry DW, Townsend RN. Low-dose vasopressin in the treatment of vasodilatory septic shock. J Trauma. 1999;47(4):699-703 discussion 703-5.

36. Kern H, Schröder T, Kaulfuss M, Martin M, Kox WJ, Spies CD. Enoximone in contrast to dobutamine improves hepatosplanchnic function in fluidoptimized septic shock patients. Crit Care Med. 2001;29(8):1519-25.

37. Seguin P, Bellissant E, Le Tulzo Y, Laviolle B, Lessard Y, Thomas R, et al. Effects of epinephrine compared with the combination of dobutamine and norepinephrine on gastric perfusion in septic shock. Clin Pharmacol Ther. 2002;71(5):381-8.
38. Patel BM, Chittock DR, Russell JA, Walley KR. Beneficial effects of short-term vasopressin infusion during severe septic shock. Anesthesiology. 2002;96(3): $576-82$.

39. Dünser MW, Mayr AJ, Ulmer H, Knotzer H, Sumann G, Pajk W, et al. Arginine vasopressin in advanced vasodilatory shock: a prospective, randomized, controlled study. Circulation. 2003;107(18):2313-9.

40. Morelli A, De Castro S, Teboul JL, Singer M, Rocco M, Conti G, et al. Effects of levosimendan on systemic and regional hemodynamics in septic myocardial depression. Intensive Care Med. 2005;31(5):638-44.

41. Albanèse J, Leone $M$, Delmas $A$, Martin C. Terlipressin or norepinephrine in hyperdynamic septic shock: a prospective, randomized study. Crit Care Med. 2005;33(9):1897-902

42. Luckner G, Dünser MW, Stadlbauer KH, Mayr VD, Jochberger S, Wenzel V, et al. Cutaneous vascular reactivity and flow motion response to vasopressin in advanced vasodilatory shock and severe postoperative multiple organ dysfunction syndrome. Crit Care. 2006;10(2):R40.

43. Seguin P, Laviolle B, Guinet P, Morel I, Mallédant Y, Bellissant E. Dopexamine and norepinephrine versus epinephrine on gastric perfusion in patients with septic shock: a randomized study [NCT00134212]. Crit Care. 2006;10(1): R32.

44. Schmoelz M, Schelling G, Dunker M, Irlbeck M. Comparison of systemic and renal effects of dopexamine and dopamine in norepinephrine-treated septic shock. J Cardiothorac Vasc Anesth. 2006;20(2):173-8.

45. Lauzier F, Lévy B, Lamarre P, Lesur O. Vasopressin or norepinephrine in early hyperdynamic septic shock: a randomized clinical trial. Intensive Care Med. 2006;32(11):1782-9.

46. Mathur SK, Dhunna R, Chakraborty A. Comparison of norepinephrine and dopamine in the management of septic shock using impedance cardiography. Indian J Crit Care Med. 2007;11(4):184-91.

47. Annane D, Vignon P, Renault A, Bollaert PE, Charpentier C, Martin C, et al. Norepinephrine plus dobutamine versus epinephrine alone for management of septic shock: a randomised trial. Lancet. 2007;370(9588): 676-84

48. Myburgh JA, Higgins A, Jovanovska A, Lipman J, Ramakrishnan N, Santamaria J, et al. A comparison of epinephrine and norepinephrine in critically ill patients. Intensive Care Med. 2008:34(12):2226-34.

49. Morelli A, Ertmer C, Lange M, Dünser M, Rehberg S, Van Aken H, et al. Effects of short-term simultaneous infusion of dobutamine and terlipressin in patients with septic shock: the DOBUPRESS study. Br J Anaesth. 2008; 100(4):494-503.

50. Morelli A, Ertmer C, Rehberg S, Lange M, Orecchioni A, Laderchi A, et al. Phenylephrine versus norepinephrine for initial hemodynamic support of patients with septic shock: a randomized, controlled trial. Crit Care. 2008; 12(6):R143.

51. Russell JA, Walley KR, Singer J, Gordon AC, Hébert PC, Cooper DJ, et al. Vasopressin versus norepinephrine infusion in patients with septic shock. N Engl J Med. 2008;358(9):877-87.

52. Morelli A, Ertmer C, Rehberg S, Lange M, Orecchioni A, Cecchini V, et al. Continuous terlipressin versus vasopressin infusion in septic shock (TERLIVAP): a randomized, controlled pilot study. Crit Care. 2009;13(4):R130.

53. Alhashemi JA, Alotaibi QA, Abdullah GM, Shalabi SA. Levosimendan vs dobutamine in septic shock. J Crit Care. 2009;24(3):e14-5.

54. De Backer D, Biston P, Devriendt J, Madl C, Chochrad D, Aldecoa C, et al. Comparison of dopamine and norepinephrine in the treatment of shock. $\mathrm{N}$ Engl J Med. 2010;362(9):779-89.

55. Jain G, Singh DK. Comparison of phenylephrine and norepinephrine in the management of dopamine-resistantseptic shock. Indian J Crit Care Med. 2010;14(1):29-34.

56. Patel GP, Grahe JS, Sperry M, Singla S, Elpern E, Lateef O, et al. Efficacy and safety of dopamine versus norepinephrine in the management of septic shock. Shock. 2010;33(4):375-80.

57. Morelli A, Donati A, Ertmer C, Rehberg S, Lange M, Orecchioni A, et al. Levosimendan for resuscitating the microcirculation in patients with septic shock: a randomized controlled study. Crit Care. 2010;14(6):R232.

58. Morelli A, Donati A, Ertmer C, Rehberg S, Kampmeier T, Orecchioni A, et al. Effects of vasopressinergic receptor agonists on sublingual microcirculation in norepinephrine-dependent septic shock. Crit Care. 2011;15(5):R217.

59. Han XD, Sun H, Huang XY, Zhang SY, Wang YD, Ren K, et al. A clinical study of pituitrin versus norepinephrine in the treatment of patients with septic shock. Zhongguo Wei Zhong Bing Ji Jiu Yi Xue. 2012;24(1):33-7. 
60. Mahmoud KM, Ammar AS. Norepinephrine supplemented with dobutamine or epinephrine for the cardiovascular support of patients with septic shock. Indian J Crit Care Med. 2012;16(2):75-80.

61. Memis D, Inal MT, Sut N. The effects of levosimendan vs dobutamine added to dopamine on liver functions assessed with noninvasive liver function monitoring in patients with septic shock. J Crit Care. 2012;27(3):318 e1-6.

62. Mehta S, Granton J, Gordon AC, Cook DJ, Lapinsky S, Newton G, et al. Cardiac ischemia in patients with septic shock randomized to vasopressin or norepinephrine. Crit Care. 2013;17(3):R117.

63. Hua F, Wang $X$, Zhu L. Terlipressin decreases vascular endothelial growth factor expression and improves oxygenation in patients with acute respiratory distress syndrome and shock. J Emerg Med. 2013;44(2):434-9.

64. Fang M, Dong S. Effects of levosimendan on hemodynamics and cardiac function in patients with septic shock. Zhonghua Wei Zhong Bing Ji Jiu Yi Xue. 2014:26(10):692-6.

65. Torraco A, Carrozzo R, Piemonte F, Pastore A, Tozzi G, Verrigni D, et al. Effects of levosimendan on mitochondrial function in patients with septic shock: a randomized trial. Biochimie. 2014;102:166-73.

66. Gordon AC, Mason AJ, Thirunavukkarasu N, Perkins GD, Cecconi M, Cepkova $M$, et al. Effect of Early Vasopressin vs Norepinephrine on Kidney Failure in Patients With Septic Shock: The VANISH Randomized Clinical Trial. JAMA. 2016;316(5):509-18.

67. Xiao X, Zhang J, Wang Y, Zhou J, Zhu Y, Jiang D, et al. Effects of terlipressin on patients with sepsis via improving tissue blood flow. J Surg Res. 2016; 200(1):274-82.

68. Gordon AC, Perkins GD, Singer M, McAuley DF, Orme RM, Santhakumaran S, et al. Levosimendan for the Prevention of Acute Organ Dysfunction in Sepsis. N Engl J Med. 2016;375(17):1638-48.

69. Meng JB, Hu MH, Lai ZZ, Ji CL, Xu XJ, Zhang G, et al. Levosimendan Versus Dobutamine in Myocardial Injury Patients with Septic Shock: A Randomized Controlled Trial. Med Sci Monit. 2016;22:1486-96.

70. Barzegar E, Ahmadi A, Mousavi S, Nouri M, Mojtahedzadeh M. The Therapeutic Role of Vasopressin on Improving Lactate Clearance During and After Vasogenic Shock: Microcirculation, Is It The Black Box? Acta Med Iran. 2016;54(1):15-23.

71. Choudhury A, Kedarisetty CK, Vashishtha C, Saini D, Kumar S, Maiwall R, et al. A randomized trial comparing terlipressin and noradrenaline in patients with cirrhosis and septic shock. Liver Int. 2017;37(4):552-61.

72. Chen Z, Zhou P, Lu Y, Yang C. Comparison of effect of norepinephrine and terlipressin on patients with ARDS combined with septic shock: a prospective single-blind randomized controlled trial. Zhonghua Wei Zhong Bing Ji Jiu Yi Xue. 2017;29(2):111-6.

73. Hajjej Z, Meddeb B, Sellami W, Labbene I, Morelli A, Ferjani M. Effects of Levosimendan on Cellular Metabolic Alterations in Patients With Septic Shock: A Randomized Controlled Pilot Study. Shock. 2017;48(3):307-12.

\section{Ready to submit your research? Choose BMC and benefit from:}

- fast, convenient online submission

- thorough peer review by experienced researchers in your field

- rapid publication on acceptance

- support for research data, including large and complex data types

- gold Open Access which fosters wider collaboration and increased citations

- maximum visibility for your research: over $100 \mathrm{M}$ website views per year

At BMC, research is always in progress.

Learn more biomedcentral.com/submissions 